\title{
Front Matter: Volume 8464
}

, "Front Matter: Volume 8464," Proc. SPIE 8464, Nanobiosystems:

Processing, Characterization, and Applications V, 846401 (10 October 2012); doi: $10.1117 / 12.2010308$

SPIE Event: SPIE NanoScience + Engineering, 2012, San Diego, California, United SPIE. States 


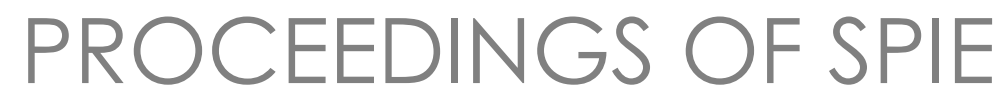

\title{
Nanobiosystems: Processing, Characterization, and Applications V
}

\author{
Norihisa Kobayashi \\ Fahima Ouchen \\ lleana Rau \\ Editors
}

12-15 August 2012

San Diego, California, United States

Sponsored and Published by

SPIE 
The papers included in this volume were part of the technical conference cited on the cover and title page. Papers were selected and subject to review by the editors and conference program committee. Some conference presentations may not be available for publication. The papers published in these proceedings reflect the work and thoughts of the authors and are published herein as submitted. The publisher is not responsible for the validity of the information or for any outcomes resulting from reliance thereon.

Please use the following format to cite material from this book:

Author(s), "Title of Paper," in Nanobiosystems: Processing, Characterization, and Applications $V$, edited by Norihisa Kobayashi, Fahima Ouchen, lleana Rau, Proceedings of SPIE Vol. 8464 (SPIE, Bellingham, WA, 2012) Article CID Number.

ISSN: 0277-786X

ISBN: 9780819491817

Published by

SPIE

P.O. Box 10, Bellingham, Washington 98227-0010 USA

Telephone +1 3606763290 (Pacific Time) · Fax +1 3606471445

SPIE.org

Copyright (@ 2012, Society of Photo-Optical Instrumentation Engineers.

Copying of material in this book for internal or personal use, or for the internal or personal use of specific clients, beyond the fair use provisions granted by the U.S. Copyright Law is authorized by SPIE subject to payment of copying fees. The Transactional Reporting Service base fee for this volume is $\$ 18.00$ per article (or portion thereof), which should be paid directly to the Copyright Clearance Center (CCC), 222 Rosewood Drive, Danvers, MA 01923. Payment may also be made electronically through CCC Online at copyright.com. Other copying for republication, resale, advertising or promotion, or any form of systematic or multiple reproduction of any material in this book is prohibited except with permission in writing from the publisher. The CCC fee code is 0277-786X/12/\$18.00.

Printed in the United States of America.

Publication of record for individual papers is online in the SPIE Digital Library.

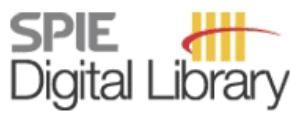

SPIEDigitalLibrary.org

Paper Numbering: Proceedings of SPIE follow an e-First publication model, with papers published first online and then in print and on CD-ROM. Papers are published as they are submitted and meet publication criteria. A unique, consistent, permanent citation identifier (CID) number is assigned to each article at the time of the first publication. Utilization of CIDs allows articles to be fully citable as soon as they are published online, and connects the same identifier to all online, print, and electronic versions of the publication. SPIE uses a six-digit CID article numbering system in which:

- The first four digits correspond to the SPIE volume number.

- The last two digits indicate publication order within the volume using a Base 36 numbering

system employing both numerals and letters. These two-number sets start with 00, 01, 02, 03, 04,

05, 06, 07, 08, 09, OA, OB ... 0Z, followed by 10-1Z, 20-2Z, etc.

The CID Number appears on each page of the manuscript. The complete citation is used on the first page,

and an abbreviated version on subsequent pages. Numbers in the index correspond to the last two digits of the six-digit CID Number. 


\section{Contents}

vii Conference Committee

SESSION 1

846402 Solid state lighting using deoxyribonucleic acid-phosphor blend (Invited Paper) [8464-1] J. G. Grote, T. Gorman, Air Force Research Lab. (United States); F. Ouchen, Air Force Research Lab. (United States) and Univ. of Dayton Research Institute (United States)

846403 DNA nano-circuit for electronics (Keynote Paper) [8464-2]

N. Ogata, Ogata Research Lab., Ltd. (Japan)

846404 Kinetics of grating inscription in DR1:DNA-CTMA thin film: experiment and semiintercalation approach (Keynote Paper) [8464-3]

G. Pawlik, W. Radosz, A. C. Mitus, J. Mysliwiec, A. Miniewicz, Wroclaw Univ. of Technology (Poland); F. Kajzar, Politehnica Univ. of Bucharest (Romania) and Institut des Sciences et Technologies Moléculaires d'Angers, CNRS, Univ. d'Angers (France); I. Rau, Politehnica Univ. of Bucharest (Romania); J. G. Grote, Air Force Research Lab. (United States)

SESSION 2

846406 Electronic properties of DNA-surfactant complex and its application to DNA-based bioorganic field effect transistor memory (Invited Paper) [8464-5]

L. Liang, T. Yukimoto, Chiba Univ. (Japan); S. Uemura, T. Kamata, National Institute of Advanced Industrial Science and Technology (Japan); K. Nakamura, N. Kobayashi, Chiba Univ. (Japan)

\section{SESSION 3}

846409 DNA-based thin-film dielectrics for potential application as gate insulators in OFETs [8464-9] F. Ouchen, N. Venkat, Univ. of Dayton Research Institute (United States) and Air Force Research Lab. (United States); K. M. Singh, UES, Inc. (United States) and Air Force Research Lab. (United States); M. Shin, D. M. Joyce, Air Force Research Lab. (United States); P. P. Yaney, Univ. of Dayton (United States) and Air Force Research Lab. (United States); E. M. Heckman, C. M. Bartsch, J. G. Grote, Air Force Research Lab. (United States) 
8464 OC Influence of surfactant on dynamics of photoinduced motions in a dye-doped deoxyribonucleic acid (Invited Paper) [8464-12]

J. Mysliwiec, K. Parafiniuk, A. Miniewicz, Wroclaw Univ. of Technology (Poland); I. Rau, F. Kajzar, Politehnica Univ. of Bucharest (Romania); J. Niziol, AGH Univ. of Science and Technology (Poland); E. Hebda, J. Pielichowski, Crakow Univ. of Technology (Poland);

B. Sahraoui, Lab. MOLTECH-Anjou, CNRS, Univ. d'Angers (France)

8464 OD Novel cationic dye and crosslinkable surfactant for DNA biophotonics [8464-13]

L. E. Johnson, L. N. Latimer, S. J. Benight, Z. H. Watanabe, D. L. Elder, B. H. Robinson, Univ. of Washington (United States); C. M. Bartsch, E. M. Heckman, Air Force Research Lab. (United States); G. Depotter, K. Clays, Katholieke Univ. Leuven (Belgium)

8464 OE Tunable DFB lasers based on DNA-surfactant-dye complexes (Invited Paper) [8464-14]

T. Chida, Y. Kawabe, Chitose Institute of Science and Technology (Japan)

NANOBIOSYSTEMS AND OPTICAL PROCESSES IN ORGANIC MATERIALS AND NANOSTRUCTURES: JOINT SESSION WITH CONFERENCE 8474

84640 Ol Optoelectronics using DNA as a template for dyes (Keynote Paper) [8464-7]

D. Mamangun, D. Navarathne, G. A. Sotzing, Univ. of Connecticut (United States);

J. P. Lombardi, C. M. Bartsch, E. M. Heckman, K. M. Singh, J. G. Grote, T. R. Nelson, Jr., Air

Force Research Lab. (United States)

\section{SESSION 7}

8464 OM DNA, sugars, and proteins at work in optics (Keynote Paper) [8464-22]

K. Clays, Katholieke Univ. Leuven (Belgium) and Washington State Univ. (United States)

8464 ON Organic nanoparticles as a central plateform of magnetofluorescent nano-assemblies toward two-photon bioimaging applications (Invited Paper) [8464-23]

A. Faucon, R. Lenk, J. Hemez, CEISAM, CNRS, Univ. de Nantes (France); E. Gautron, IMN, CNRS, Univ. de Nantes (France); J. Fresnais, PECSA, CNRS, Univ. Paris 6 (France); J.-F. Berret, MSC, CNRS, Univ. Paris 7 Diderot (France); E. Ishow, CEISAM, CNRS, Univ. de Nantes (France)

846400 Fluorescence and SHG in organic nanocrystals of DCNP (Invited Paper) [8464-24] A. Miniewicz, K. Palewska, P. Karpinski, L. Sznitko, Wroclaw Univ. of Technology (Poland); M. Zielinski, Lab. de Photonique Quantique et Moléculaire, CNRS, Ecole Normale Supérieure de Cachan (France) 
8464 OP Advances in DNA photonics (Keynote Paper) [8464-25]

E. M. Heckman, Air Force Research Lab. (United States); R. S. Aga, General Dynamics Information Technology (United States); E. M. Fehrman Cory, Univ. of Dayton (United States); F. Ouchen, Univ. of Dayton Research Institute (United States); A. Lesko, B. Telek, Univ. of Dayton (United States); J. Lombardi, C. M. Bartsch, J. G. Grote, Air Force Research Lab. (United States)

\section{SESSION 9}

8464 OT Bio-dielectric organic-inorganic hybrid films for potential energy storage applications [8464-29]

D. M. Joyce, Air Force Research Lab. (United States); N. Venkat, F. Ouchen, Air Force Research Lab. (United States) and Univ. of Dayton Research Institute (United States); K. M. Singh, Air Force Research Lab. (United States) and UES, Inc. (United States); S. R. Smith, Air Force Research Lab. (United States) and Univ. of Dayton Research Institute (United States); J. G. Grote, Air Force Research Lab. (United States)

\section{POSTER SESSION}

$8464 \mathrm{OZ}$ Extension of the spectral range of bacteriorhodopsin functional activity by energy transfer from quantum dots [8464-35]

$\vee$. Oleinikov, Moscow Engineering Physics Institute (Russian Federation) and Shemyakin \& Ovchinnikov Institute of Bioorganic Chemistry (Russian Federation); N. Bouchonville, Univ. de Reims Champagne-Ardenne (France); A. Sukhanova, Moscow Engineering Physics Institute (Russian Federation) and Trinity College Dublin (Ireland); M. Molinari, Univ. de Reims Champagne-Ardenne (France); S. Sizova, K. Mochalov, A. Chistyakov, Moscow Engineering Physics Institute (Russian Federation) and Shemyakin \& Ovchinnikov Institute of Bioorganic Chemistry (Russian Federation); E. Lukashev, Moscow Engineering Physics Institute (Russian Federation); A. Rakovich, J. F. Donegan, Trinity College Dublin (Ireland); I. Nabiev, Moscow Engineering Physics Institute (Russian Federation) and Trinity College Dublin (Ireland)

846410 Hyperspectral polarized light scattering to study tumor cells in in-vitro samples [8464-36] N. Riviere, R. Ceolato, ONERA (France); C. Lorenzo, R. Jorand, B. Ducommun, Institut des Technologies Avancées en Sciences du Vivant, CNRS (France)

846411 Synthesis and characterization of porous nanocrystalline biphasic calcium phosphate for bio applications [8464-37]

P. M. S. L. Shanthi, M. Ashok, T. Balasubramanian, National Institute of Technology, Tiruchirappalli (India)

Author Index 
Proc. of SPIE Vol. $8464846401-6$

Downloaded From: https://www.spiedigitallibrary.org/conference-proceedings-of-spie on 26 Apr 2023 Terms of Use: https://www.spiedigitallibrary.org/terms-of-use 


\section{Conference Committee}

Symposium Chairs

David L. Andrews, University of East Anglia Norwich (United Kingdom) James G. Grote, Air Force Research Laboratory (United States)

Symposium Cochairs

Satoshi Kawata, Osaka University (Japan)

Manijeh Razeghi, Northwestern University (United States)

Conference Chairs

Norihisa Kobayashi, Chiba University (Japan)

Fahima Ouchen, Air Force Research Laboratory (United States)

Ileana Rau, Politehnica University of Bucharest (Romania)

Conference Program Committee

Carrie M. Bartsch, Air Force Research Laboratory (United States)

Liming Dai, Case Western Reserve University (United States)

Ananth Dodabalapur, The University of Texas at Austin (United States)

James G. Grote, Air Force Research Laboratory (United States)

Emily M. Heckman, Air Force Research Laboratory (United States)

Kuniharu Ijiro, Hokkaido University (Japan)

Jung-II Jin, Korea University (Korea, Republic of)

François Kajzar, Politehnica University of Bucharest (Romania)

Sang Nyon Kim, Air Force Research Laboratory (United States)

Oksana Krupka, Université d'Angers (France)

Charles Y. C. Lee, Air Force Office of Scientific Research

(United States)

Misoon Y. Mah, Air Force Office of Scientific Research (United States)

Naoya Ogata, Chitose Institute of Science and Technology (Japan)

Bruce H. Robinson, University of Washington (United States)

Anna Samoc, The Australian National University (Australia)

Marek J. Samoc, Wroclaw University of Technology (Poland)

Niyazi Serdar Sariciftci, Johannes Kepler University of Linz (Austria)

Kristi M. Singh, Air Force Research Laboratory (United States)

Andrew J. Steckl, University of Cincinnati (United States)

Morley O. Stone, Air Force Research Laboratory (United States)

Perry P. Yaney, University of Dayton (United States) 
Session Chairs

1 Fahima Ouchen, Air Force Research Laboratory (United States)

2 Olaf Karthaus, Chitose Institute of Science and Technology (Japan)

3 Jaroslaw Mysliwiec, Wroclaw University of Technology (Poland)

4 Norihisa Kobayashi, Chiba University (Japan)

5 Nanobiosystems and Optical Processes in Organic Materials and Nanostructures: Joint Session with Con James G. Grote, Air Force Research Laboratory (United States) Rachel Jakubiak, Air Force Research Laboratory (United States)

6 Koen Clays, Katholieke Universiteit Leuven (Belgium)

7 Roberto Zamboni, Istituto per la Sintesi Organica e la Fotoreattività Italy

8 Andrzej Miniewicz, Wroclaw University of Technology (Poland)

9 lleana Rau, Politehnica University of Bucharest (Romania) 